\title{
INDICATIONS FOR CORONARY ANGIOPLASTY IN ACUTE MYOCARDIAL ISCHEMIC SYNDROMES
}

SUMMARY. The role of coronary angioplasty for the treatment of patients with evolving myocardial infarction, unstable angina, and early postinfarction unstable angina is discussed.

It has been shown that coronary angioplasty in patients with an evolving myocardial infarction is feasible and can be performed with a high initial success rate. The most beneficial timing of dilatation is still unclear, and acute reocclusion following coronary angioplasty remains a problem. Current data suggest that the left ventricular function is greater improved and peri-infarction ischemia is less with angioplasty when compared with sole thrombolytic treatment.

Coronary angioplasty for unstable angina and early postinfarction unstable angina can be performed with a high initial success rate, but at an increased risk of major complications.

Thus, coronary angioplasty has nowadays obtained a definitive place in the treatment of acute myocardial ischemic syndromes. Further research is needed to improve the initial and late results of coronary angioplasty, and additional randomized clinical studies are necessary to more accurately define the indications and timing of dilatation in these acutely ill patients.

KEY WORDS. unstable angina, angioplasty, angina, acute myocardial infarction, coronary artery bypass grafting

Transluminal angioplasty, performed to widen the lumen of a stenotic vessel by means of an intravascular catheter, was conceived by Dotter and Judkins in 1964 [1]. This technique proved effective in peripheral arteries. However, it took until 1977 before Gruentzig used this method to dilate the coronary arteries of conscious humans [2]. Subsequent improvements in equipment and technique have established coronary angioplasty as a major treatment mode for stable angina in patients with single-vessel disease. Recently, the initial restricted indications have been widened to include dilatation of complex lesions, multivessel lesions, and vein grafts. Furthermore, angioplasty has now been shown to play an important role in the management of unstable angina and acute myocardial infarction. The purpose of this paper is to review recent developments in coronary angioplasty for the management of patients with 1) unstable angina, either refractory to or initially stabilized with optimal pharmacological treatment, 2) early postinfarction angina, and 3 ) evolving myocardial infarction.

\author{
Pim J. de Feyter, Patrick W. Serruys, \\ Paul G. Hugenholtz \\ Thoraxcenter \\ Erasmus University and University Hospital Dijkzigt \\ Rotterdam, The Netherlands
}

\section{Management of Unstable Angina Syndrome}

Unstable angina, defined as chest pain at rest accompanied with significant electrocardiographic ST-T changes, but without enzyme elevation, is a clinical syndrome that requires aggressive management because it carries an increased risk of mortality and morbidity. This is more so when optimal pharmacological treatment with nitrates, beta blockers, and $\mathrm{Ca}$ antagonists have proven to be inadequate [3, 4]. Since the causes of unstable angina are multifactorial [5-8], and within the same patient different pathophysiological mechanisms may occur at different times and in succession, it is difficult to decide what the optimal therapy for a particular stage of the disease at a particular moment in time for a patient consists of. Therefore, although treatment must be highly tailored to individual needs, one cannot afford to lose too much time awaiting the response to one or another agent. So when pain persists after initial therapy with nitrates, it usually will be directed against all suspected pathophysiological mechanisms at the same time, e.g., beta blockade, Ca entry blockers, anticoagulants, and sedatives. Basically, such treatment is aimed at restoring coronary blood flow by means of vasodilation, while also reducing overall myocardial oxygen demands. The uncertainty of outcome in a specific patient forces one to provide "maximal" treatment from the outset in order to evaluate its efficacy frequently, and early experience has shown that relief of all signs and symptoms of ischemia should be prompt, i.e., within

Address for correspondence and reprint requests: Pim $\mathrm{J}$ de Feyter, M.D., Catheterization Laboratory, Thoraxcenter, Erasmus University, Postbus 1738, 3000 DR Rotterdam, The Netherlands. 
24 hours or less. The longer and the more frequent the attacks are, the more likely it is that obstruction of the vessel is increasing. In refractory ischemia, acute revascularization by means of PTCA or CABG should be carried out. Elective revascularization should be performed in patients who are still symptomatic after optimal pharmacological treatment. Coronary angioplasty, as an initial alternative to bypass surgery, has been shown to be effective for the treatment of selected patients with unstable angina, both to relieve acute ischemic symptoms and to prevent progression to (re)infarction or cardiac death. The preference of coronary angioplasty above CABG in these critically ill patients is related to the avoidance of the intrinsic risks of major surgery and anesthesia, its rapid implementation, and its reduction of in-hospital stays and costs.

\section{Coronary Angioplasty for Initially Stabilized Unstable Angina and Refractory Unstable Angina}

The need for surgery or, alternatively, coronary angioplasty is obvious in patients with unstable angina who are refractory to optimal pharmacological treatment. Although initial pharmacological treatment may relieve the acute phase symptoms, patients remain at high risk for progression to myocardial infarction or cardiac death, and the need for coronary bypass surgery is not reduced [9]. The coronary artery obstruction in patients with unstable angina is at risk of becoming a permanent occlusion leading to myocardial infarction or death $[10,11]$. It has now been shown that coronary angioplasty is relatively safe and can be performed with a high success rate in unstable angina that is either refractory to optimal pharmacological treatment [12-14] or is initially stabilized after treatment [15-17] (Table 1). The reported lower success rate of $63 \%$ to $76 \%$ was achieved with a nonsteerable

Table 1. Coronary angioplasty for initially stabilized unstable angina, refractory unstable angina, and early postinfarction unstable angina

\begin{tabular}{|c|c|c|c|c|c|c|c|c|c|}
\hline \multirow{4}{*}{ Author } & \multirow{4}{*}{ No. PT } & \multirow{4}{*}{$\begin{array}{c}\text { Success } \\
\text { rate } \\
\%\end{array}$} & \multicolumn{3}{|c|}{ Major complication rate } & \multicolumn{3}{|c|}{$\begin{array}{l}\text { Coronary events after } \\
\text { successful angioplasty }\end{array}$} & \multirow{4}{*}{$\begin{array}{c}\text { Follow-up } \\
\text { months } \\
\text { mean }\end{array}$} \\
\hline & & & death & MI & acute surgery & death & MI & $\mathrm{AP}$ & \\
\hline & & & $\%$ & $\%$ & $\%$ & $\%$ & $\%$ & $\%$ & \\
\hline & & & \multicolumn{6}{|c|}{ INITIALLY STABILIZED UNSTABLE ANGINA } & \\
\hline \multicolumn{10}{|l|}{ Faxon $^{1,2}$} \\
\hline 1983 [15] & 442 & 63 & 0.9 & 8 & - & 1.7 & 1.5 & 18 & 18 \\
\hline \multicolumn{10}{|l|}{ Quigley } \\
\hline $1986[16]$ & 25 & 81 & 4 & 12 & 12 & 0 & 0 & 32 & 18 \\
\hline \multicolumn{10}{|l|}{ De Feyter } \\
\hline $1987[17]$ & 71 & 87 & 0 & 10 & 12 & 2 & 2 & 23 & 12 \\
\hline \multicolumn{10}{|c|}{ REFRACTORY UNSTABLE ANGINA } \\
\hline
\end{tabular}

\section{Williams $^{1}$}

$1981[12]$

Meyer $^{1}$

1983 [13]

de Feyter

1985 [14]

$\begin{array}{ll}17 & 76 \\ 50 & 9\end{array}$

76
74
93

$\begin{array}{ll}0 & 0 \\ 0 & 4\end{array}$

$\begin{array}{lcccc}6 & 0 & 0 & 8 & 10.5 \\ 2 & 0 & 0 & 36 & 6 \\ 7 & 2 & 0 & 13 & 9\end{array}$

$\begin{array}{ccc}0 & 7 & 7 \\ \text { EARLY POSTINFARCTION UNSTABLE ANGINA }\end{array}$

\begin{tabular}{|c|c|c|c|c|c|}
\hline \multicolumn{6}{|l|}{ de Feyter } \\
\hline $1986[40]$ & 53 & 89 & 0 & 8 & \\
\hline Gottlieb & & & & & \\
\hline $1986[41]$ & 47 & 91 & 0 & - & - \\
\hline Holt & & & & & \\
\hline $1986[42]$ & 69 & 80 & 2 & - & 12 \\
\hline
\end{tabular}




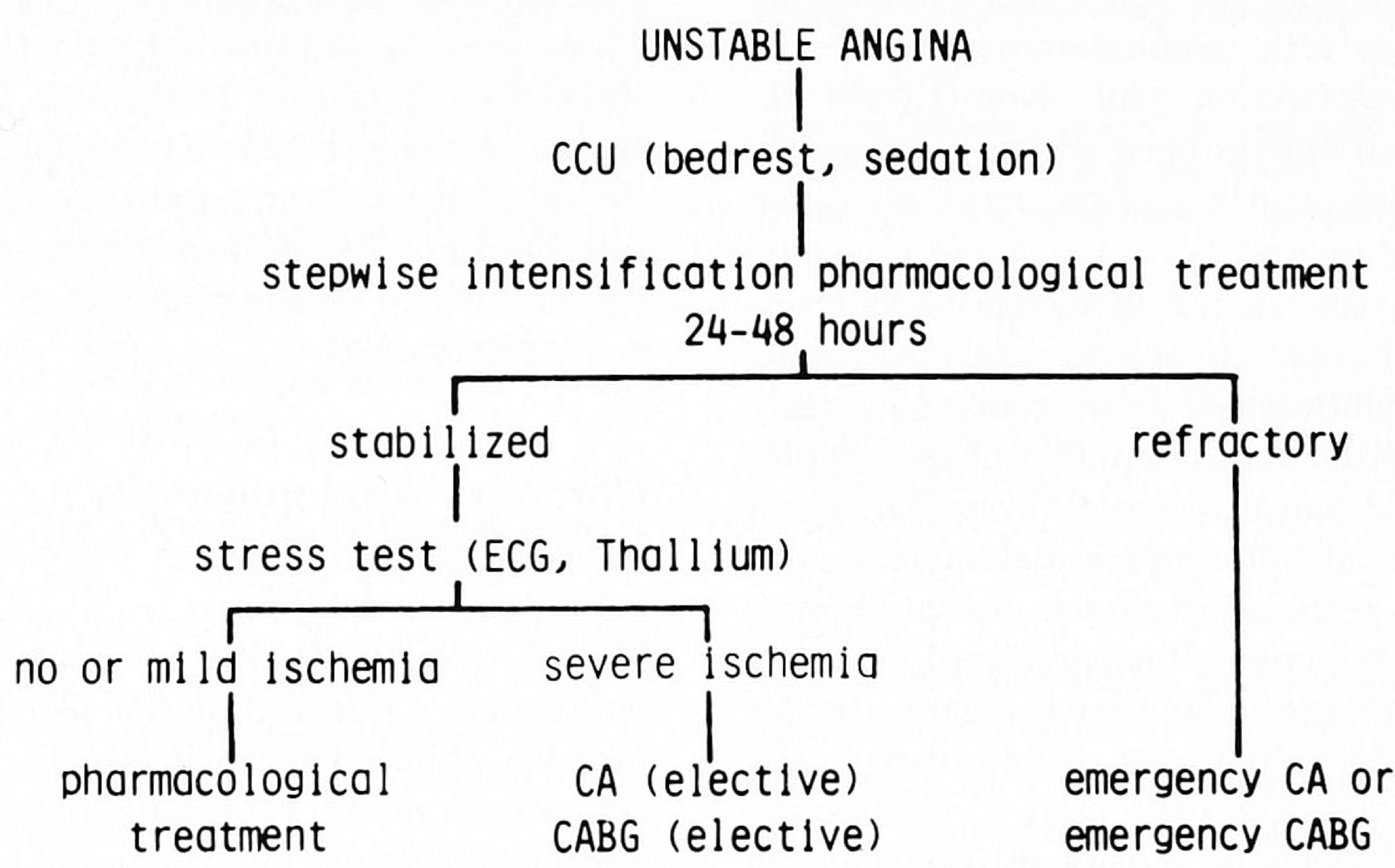

Fig. 1. Proposed management of patients with unstable angina. For all patients with unstable angina inclusive of early postinfarction angina. Pharmacological treatment includes, in all patients, anticoagulation (heparin, aspirin) and individually tailored therapy of either nitroglycerin (s.l., i.v.), beta-adrenoceptor agonists, and calcium antagonists, either alone or in combination. $C A$ : coronary angioplasty; $C A B G$ : coronary artery bypass grafting; $C C U$ : coronary care unit.

dilatation catheter, whereas the initial success rate of $81 \%$ to $93 \%$ was achieved with a steerable dilatation catheter. The latter figure reflects the current state-ofthe-art, and the initial success rate achieved in unstable angina is somewhat lower than the greater than $90 \%$ success rate reported in series of patients with stable angina pectoris $[18,19]$.

A significant amount of complications (death, myocardial infarction, urgent bypass surgery) occurred more often in patients with unstable angina than in patients with stable angina [18-20]. Procedure-related death occurred between $0 \%$ and $4 \%$; this is less than $1 \%$ for stable angina [18-20]. The procedure-related myocardial infarction rate varied from $0 \%$ up to $12 \%$; this rate is substantially higher than the $4 \%$ rate reported for stable angina [18-20]. In addition, the need for urgent bypass surgery is higher ( $2 \%$ to $12 \%$ versus $4 \%)$ for an elective procedure. An explanation for the higher complication rate may be due to, besides the clinical instability, the presence of severe or eccentric lesions being higher in patients with unstable angina [21]. These lesions have been shown to be associated with a higher rate of major complications [20,22]. The angiographic restenosis rate and recurrence of angina after an initial successful coronary angioplasty is favorable and appears to be comparable to those of patients with stable angina. $[15,17]$.

Thus coronary angioplasty can be performed at an acceptable risk and with a high initial success rate in patients with unstable angina either refractory to or stabilized after pharmacological treatment. However, these results are obtained in selected patients and those with predominantly single-vessel disease and well preserved left ventricular function.

\section{Coronary Angioplasty for Early Postinfarction Angina}

The recurrence of angina after sustained myocardial infarction, but still during the hospitalization period, is reported to be between $18 \%$ and $57 \%$ [23-28]. Early postinfarction angina is considered to have a poor short-term and long-term prognosis [23-27]. The incidence of early nonfatal reinfarction in patients with early postinfarction angina ranges between $19 \%$ and $34 \%[23,24]$. Reinfarction in these patients is therefore a serious complication, as it carries an in-hospital mortality of $20 \%$ to $36 \%$ versus $9 \%$ to $13 \%$ for patients 
without reinfarction $[24,26]$. The 1 year survival rate was $76 \%$ for those with reinfarction versus $91 \%$ for those without reinfarction [26]. Non-Q-wave infarctions have particularly been shown to be associated with a higher incidence of recurrent infarction [24, 28-31].

Uncertainty exists among cardiologists and surgeons with regard to patient selection and the timing of surgical revascularization for recurrent angina early after acute myocardial infarction. Recent reports [3439] have suggested that myocardial revascularization within the first 30 days after myocardial infarction can be accomplished with an acceptable operative mortality in selected patients, although overall mortality and morbidity rates are higher than those reported for elective surgery. Accordingly, current strategy for the management of patients with early postinfarction angina is aimed at delaying surgery until such a time when it can be performed with less inherent risks. However, in patients with severe recurrent angina, one is forced to perform immediate coronary angiography to clarify the anatomical cause(s). This is more so since coronary angioplasty, as an alternative to bypass surgery, is now an attractive option. The initial and long-term results of coronary angioplasty in small series of patients with early postinfarction unstable angina [40-42] are shown in Table 1. A myocardial infarction occurred in $8 \%$, and acute surgery was required in $8 \%$ to $12 \%$, rates that are definitely higher than those for elective coronary angioplasty [18-20]. The reason for this may be that in early postinfarction angina, the ischemia-producing lesion is still "active," and intracoronary instrumentation may more readily induce total obstruction with resulting myocardial reinfarction. These data suggest that coronary angioplasty performed early after acute myocardial infarction is relatively safe and effective in the majority of patients who have preserved left ventricular function with predominant single-vessel disease. Whether angioplasty can be performed with safety and efficacy in patients with multivessel disease or with reduced left ventricular function in the immediate postinfarction phase remains to be determined. The following management scheme for patients with unstable angina is proposed (Figure 1). Initial treatment should consist of bed rest and sedation with stepwise intensification of pharmacological treatment, highly tailored to the individual needs of a patient. If the patient is refractory to this treatment, emergency revascularization should be carried out. Patients with one- or two-vessel disease should undergo PTCA, and those with two- or three-vessel disease or left main coronary artery disease should undergo CABG. Patients who are initially stabilized should undergo exercise testing (ECG or
Thallium-201 scintigraphy) to provoke ischemia. Those with no or mild ischemia (ischemia at early stage of stress testing, inadequate blood pressure response, or a large extent of reversible perfusion defect) should, depending on extent of coronary artery disease, undergo PTCA (one- or two-vessel disease) or CABG (two- or three-vessel disease or left main coronary artery disease).

\section{Coronary Angioplasty in Acute Myocardial Infarction}

Mortality and morbidity after acute myocardial infarction are influenced by the degree of residual dysfunction of the left ventricle, which, in turn, is dependent on the size of the ultimate infarct. The concept of limiting infarct size by early recanalization of blocked coronary arteries in evolving myocardial infarction has been proven in clinical practice to be effective, and randomized studies have shown that early recanalization with streptokinase within the first few hours after the onset of symptoms will preserve left ventricular function [43-51]. In addition, in-hospital complications are reduced and 1-year follow-up survival has been shown to be improved [43-51]. Coronary angioplasty has been shown to play an (additional) important role in the management of patients with acute myocardial infarction [52-68]. The basis for this position is that with angioplasty a more complete opening of the vessel is achieved. However, the rationale for coronary angioplasty in acute evolving myocardial infarction requires further evaluation: Is direct recanalization of a blocked coronary artery without initial thrombolytic treatment preferred, or should it be instituted after failed thrombolytic treatment only?; Is dilatation of residual stenosis to optimize antegrade flow essential in order to achieve better myocardial recovery? Finally, can this procedure prevent postinfarction ischemia or reocclusion?

Advantages and disadvantages of early and delayed coronary angioplasty either in association with thrombolytic treatment or without thrombolysis are listed in Tables 2-4.

Severe residual stenosis of the infarct-related vessel is frequently present after successful thrombolysis. While initially only $40 \%$ of these patients were thought to be suitable for coronary angioplasty [52], more recently, almost all lesions are considered amenable to the procedure.

The initial success rates of coronary angioplasty with or without preceding thrombolytic therapy are listed in Table 5. This rate appears to be lower than the greater than $90 \%$ success rate that has been 
Table 2. Immediate coronary angioplasty without preceding thrombolysis (i.v. or i.c.)

\section{ADVANTAGES}

Optimizes antegrade flow

Potentiates mechanically the natural lysis phenomenon

Avoids the bleeding complications of thrombolytic therapy

Applicable to patients with contraindication for thrombolytic therapy

Economizes time and money by combining a single diagnostic and therapeutic laboratory session

\section{DISADVANTAGES}

Is a potentially lethal procedure in the setting of an acute myocardial infarction

Is a "blind procedure": distal anatomy unknown; proper size of balloon unknown

Can cause dislocation of thrombotic material

May lead to all too sudden reperfusion with reperfusion damage $\left(\mathrm{O}_{2}\right.$ and $\mathrm{Ca}^{2+}$ paradox $)$ ?

Provides no alteration of thrombogenic state

Requires staffing and maintenance of an interventional laboratory around-the-clock

achieved in elective procedures $[69,70]$. The initial success rate after a preceding failed thrombolysis was lower and varied between $57 \%$ and $83 \%$. Apparently, these lesions are also more resistant to mechanical recanalization. Procedure-related death and other major complications were reported to be rare.

Since the ultimate efficacy of reperfusion to salvage myocardium is related to the severity of the residual stenosis, the latter holds the key to outcome in the long term. Animal experiments have shown that ischemia continues when flow remains restricted. In fact, ventricular function continues to deteriorate when coronary blood flow falls below a critical threshold [71-

Table 3. Immediate (or early) coronary angioplasty after initial thrombolysis (i.c. or i.v.)

\section{ADVANTAGES}

More gradual reperfusion: $\mathrm{O}_{2}$ and $\mathrm{Ca}^{2+}$ paradox less likely

Better delineation of stenotic lesion: known distal vessel, proper size of balloon

Extent of intervention based on knowledge of severity of residual stenoses

DISADVANTAGES

Delay in achievement of optimal antegrade flow

Dilatation of a "recanalized" lesion may be complicated by a total occlusion

Uncertainty as to the degree of completion of the lytic process

Loss of time and money since therapeutic equipment for angioplasty must be inserted after removal of infusion catheter

Requires staffing and maintenance of an interventional laboratory around-the-clock.
Table 4. Delayed coronary angioplasty after lysis

\section{ADVANTAGES}

Elective procedure in optimal conditions after more comprehensive clinical assessment

Availability of surgical backup on a nonemergency basis

Persistent lytic state may have resulted in fufther (and even complete) thrombolysis

DISADVANTAGES

Potential for intercurrent reocclusion higher

Additional cost and patient discomfort due to need for a second procedure

73]. It was also shown that recovery of regional left ventricular function is greatest when the remaining stenosis after intervention either with thrombolytic agents alone or combined with PTCA is minimal [7476]. Furthermore, in a recent randomized study in a small group of patients comparing intracoronary streptokinase versus direct angioplasty, it was demonstrated that angioplasty was significantly more effective in alleviating the underlying coronary stenoses. It resulted in less peri-infarction angina and ischemia, and improved left ventricular function [61]. In another

Table 5. Success rate of coronary angioplasty in evolving myocardial infarction

\begin{tabular}{lcc}
\hline \multicolumn{3}{c}{ Immediate coronary angioplasty without thrombolysis } \\
\hline AUTHOR & NO. PATIENTS & SUCCESS RATE \% \\
Pepine 1984 [57] & 8 & 100 \\
Holmes 1985 [58] & 26 & 85 \\
Linnemeier 1985 [60] & 31 & 87 \\
O'Neill 1986 [61] & 29 & 83 \\
Rutherford 1986 [62] & 222 & 91 \\
Topol 1986 [63] & 29 & 83 \\
Marco 1987 [59] & 43 & 95
\end{tabular}

IMMEDIATE CORONARY ANGIOPLASTY AFTER SUCCESSFUL LYSIS

\begin{tabular}{lrr}
\hline Meyer 1982 [52] & 21 & 81 \\
Serruys 1983 [54] & 18 & 100 \\
Gold 1984 [64] & 12 & 75 \\
Papietro 1985 [65] & 11 & 82 \\
Erbel 1985 [66] & 117 & 69 \\
Holmes 1985 [58] & 15 & 73 \\
Thoraxcenter 1987* & 115 & 88 \\
Topol 1986 [63] & 31 & 96 \\
Kitazume 1986 [68] & 16 & 88
\end{tabular}

IMMEDIATE CORONARY ANGIOPLASTY AFTER FAILED LYSIS

\begin{tabular}{lrl}
\hline Gold 1984 [64] & 16 & 69 \\
Holmes 1985 [58] & 14 & 71 \\
Papietro 1985 [65] & 7 & 57 \\
Prida 1986 [67] & 18 & 83 \\
Kitazume 1986 [68] & 6 & 83 \\
\hline
\end{tabular}

*Not published 
randomized study, it was shown that coronary angioplasty immediately after combined i.v. or i.c. streptokinase (STK), compared to early combined i.v. or i.c. STK, was followed by an improvement in the regional left ventricular function in patients with anterior wall infarction only [77]. These results seem to justify early coronary angioplasty after thrombolytic treatment in cases with severe residual stenosis.

Reocclusion after initially successful thrombolytic therapy continues to be a significant problem. Angiographically verified reocclusion may occur in up to $25 \%$ of patients $[78,79]$. It is generally accepted that rethrombosis and reinfarction are more likely to occur in the presence of a severe residual stenosis [54, 80], and certain characteristics of the geometry of the stenosis predict that rethrombosis will take place [80]. In a few nonrandomized studies [54, 74], it has been demonstrated that in subgroups of patients treated by the combination of thrombolytic agents and coronary angioplasty, the reocclusion and reinfarction rate is lower. In fact, angiographically established reocclusion rates after initially successful thrombolysis followed by successful coronary angioplasty varies from $3 \%$ to $18 \%$, while in-hospital clinical reinfarction ranges between $11 \%$ and $18 \%$ [ $52,58,65]$. In a recently conducted randomized study, the effect of coronary angioplasty following immediately after successful thrombolytic therapy demonstrated a lower incidence of reocclusion (14\%), although this was not statistically significantly different (20\%) from those treated with lysis alone [77]. However, the number of patients studied were small.

At present, while many questions are not yet answered, we propose the following practical scheme for the management of patients with an acute myocardial infarction (Figure 2). Thrombolytic treatment should begin as soon as possible, preferably out of the hospital, in patients who present with chest pain within 4 hours of onset of symptoms. Immediate coronary evaluation should be undertaken while the perfusion of the thrombolytic agent is maintained. In case of complete occlusion, mechanical perforation and dilatation should be immediately performed. With a severe remaining stenosis, angioplasty should be performed, but not in cases with minor or moderate stenosis.

\section{Conclusion}

In the absence of a cure, the physician's objective is to palliate and protect the individual patient as much as possible and at the lowest possible risk. Aggressive intervention with thrombolytic therapy is the current preferred means of managing patients with evolving myocardial infarction, provided therapy can begin within 4 hours after the onset of symptoms. Currently, the available data on the use of PTCA following thrombolysis are limited and conflicting, and no clear answers have as yet emerged about the additional effects of PTCA on left ventricular ischemia, preservation of left ventricular function, or prevention of reocclusion. We therefore feel that, at present, PTCA following thrombolysis should not be recommended as a routine procedure for all patients, but should be restricted to those with a remaining severe stenosis or those with failed thrombolysis. The end goals are a stable clinical state, preservation of myocardial function, and consequent improvement of morbidity and mortality. These need to be balanced against potential adverse effects of the intervention. One thing has become clear: The intervention should be instituted as soon as possible after the onset of symptoms to confer maximum benefits, and large, usually anterior, infarcts show the greatest gains.

Unstable angina should also be managed with haste, initially with stepwise intensification of pharmacological therapy to produce a stable state. Early angiography is indicated if this approach fails, and coronary angioplasty should be performed when a stenosis technically suitable for dilatation and responsible for the unstable state is found. The decision in favor of dilatation in single-vessel disease is easy to make. In the presence of multivessel disease, in some patients uncertainty remains. Dilatation of the ischemia-related vessel only, as opposed to total revascularization by multiple dilatations or bypass surgery, is currently preferred, but remains to be solved on the basis of more study.

Improvements in the equipment used for coronary angioplasty, such as steerable systems and low-profile balloons, have enhanced the success rates of this approach. Further refinements, including soft-tip guiding catheters, antegrade perfusion catheters, of laser techniques, should lead to even better results and higher safety of the procedures. Restenosis and reocclusion rates remain disappointingly high and pose a serious problem that needs to be resolved, either by better pharmacological approach or by prosthesis such as intravascular stents.

Coronary angioplasty has now reached a definitive place in the treatment of acute myocardial ischemia and infarction. Research should be increased to improve the technique, to accurately define the indications for its use, and to study the timing of dilatation in this group of acutely ill patients. 


\section{Diagnosis MI (onset symptoms $<4 \mathrm{hrs}$ )}

intravenous thrombolytic agent

(ambulance?, CCU)

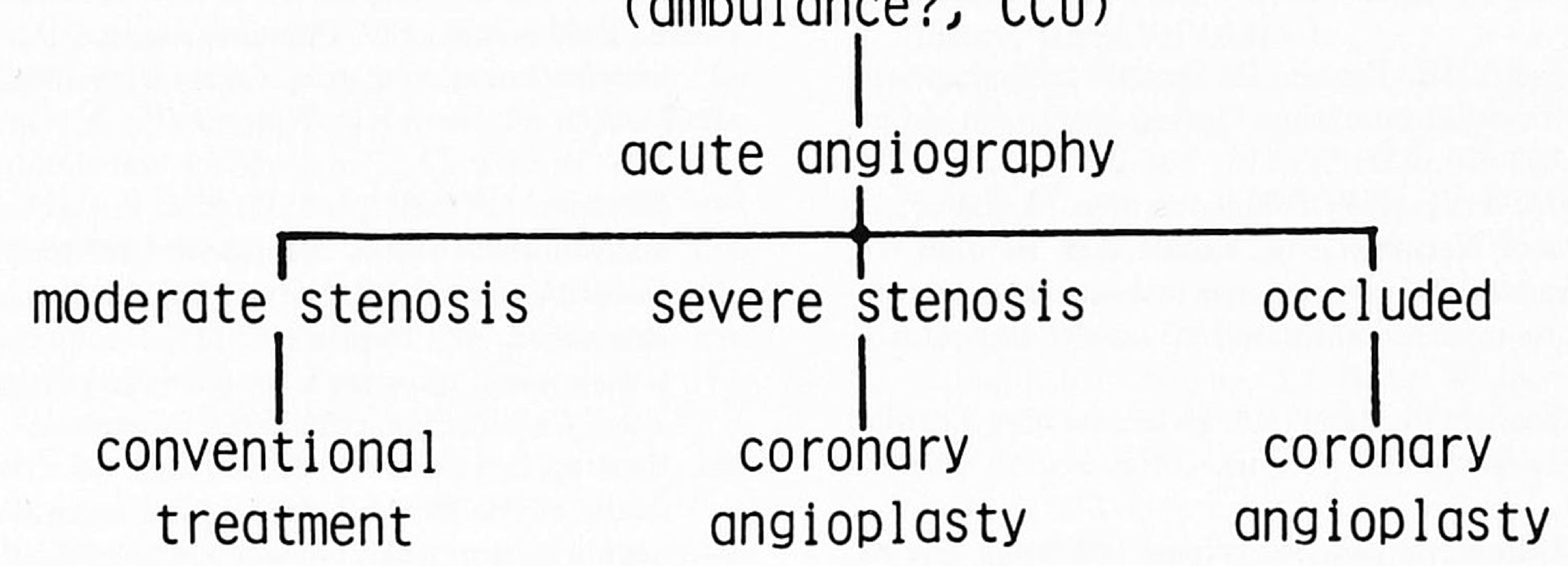

Fig. 2. Proposed management for patients with evolving myocardial infarction. MI: myocardial infarction; CCU: coronary care unit.

\section{References}

1. Dotter CT, Judkins MP. Transluminal treatment of arteriosclerotic obstruction: Description of a new technique and a preliminary report of its application. Circulation 1964;30:654-670.

2. Gruentzig AR, Senning A, Siegenthaler WE. Nonoperative dilatation of coronary artery stenoses-percutaneous transluminal coronary angioplasty. New Engl J Med 1979;301:6168.

3. Gazes PC, Mobley EM, Farris HM, Duncan RC, Humphries GB. Preinfarction (unstable) angina-a prospective study. Ten year follow-up. Circulation 1973;48:331.

4. Olson HG, Lyons KP, Aronow WS, Stinson RJ, Kuperus J, Waters HJ. The high-risk angina patients. Circulation 1981;64:674-684.

5. Maseri A, L'Abbate, Baroldi G et al. Coronary vasospasm as a possible cause of myocardial infarction: A conclusion derived from the study of "preinfarction" angina. $N$ Engl $J$ Med 1978;229:1271-1277.

6. Davies MJ, Thomas AC. Plaque fissuring-the cause of acute myocardial infarction, sudden ischemic death and crescendo angina. Br Heart $J$ 1985;53:363-373.

7. Falk E. Unstable angina with fatal outcome: Dynamic coronary thrombosis leading to infarction or sudden death. $\mathrm{Cir}$ culation 1985;71:699-708.

8. Mandelkorn JB, Wolf NM, Singh S et al. Intracoronary thrombus in nontransmural myocardial infarction and in unstable angina pectoris. Am J Cardiol 1983;52:1-6.

9. Rahimtoola SH. Coronary bypass surgery for unstable angina. Circulation 1984;69:842.

10. Moise A, Theroux P, Talymans Y, Descoings B, Lespérance J, Waters DO, Pelletier GB, Bourassa MG. Unstable angina and progression of coronary atherosclerosis. $N$ Engl J Med 1983;309:685.

11. Neill WA, Wharton TP, Fluri-Lundeen J, Cohen JS. Acute coronary insufficiency-coronary occlusion after intermittent ischemic attacks. $N$ Engl J Med 1980;302:1158.
12. Williams DO, Riley RS, Singh AK, Gewirtz H, Most AS. Evaluation of the role of coronary angioplasty in patients with unstable angina pectoris. Am Heart $J$ 1981;102:1-9.

13. Meyer J, Schmitz HJ, Kiesslich T et al. Percutaneous transluminal coronary angioplasty in patients with stable and unstable angina pectoris: Analysis of early and late results. Am Heart $J$ 1983;106:973-980.

14. de Feyter PJ, Serruys PW, van den Brand M, Balakumaran K, Mochtar B, Soward AL, Arnold AER, Hugenholtz PG. Emergency coronary angioplasty in refractory unstable angina. $N$ Engl J Med 1985;313:342-347.

15. Faxon DP, Detre KM, McGabe $\mathrm{CH}$ et al. Role of percutaneous transluminal coronary angioplasty in the treatment of unstable angina: Report from the National Heart, Lung and Blood Institute percutaneous transluminal coronary angioplasty and coronary artery surgery study registries. Am J Cardiol 1983;53:(12):131C-135C.

16. Quigley PJ, Erwin J, Maurer BJ, Walsh MJ, Gearty GF. Percutaneous transluminal coronary angioplasty in unstable angina; comparison with stable angina. $\mathrm{Br}$ Heart $J$ 1986;55:227-230.

17. de Feyter PJ, Serruys PW, Suryapranata H, Beatt K. PTCA early after the diagnosis of unstable angina. Am Heart $J$ 1987.

18. Anderson HV, Roubin GS, Leimgruber PP, Douglas JS, King SB, Gruentzig AR. Primary angiographic success rates of percutaneous transluminal coronary angioplasty. Am J Cardiol 1985;56:712-717.

19. Block PC. Percutaneous transluminal coronary angioplasty: Role in the treatment of coronary artery disease. Circulation 1985;72(Suppl V);V-161.

20. Cowley MJ, Dorros G, Kelsey SF, van Raden M, Detre K. Acute coronary events associated with percutaneous transluminal coronary angioplasty. Am J Cardiol 1984;53:12C$16 \mathrm{C}$.

21. Ambrose JA, Winters SL, Stern A, Eng A, Teichholtz LE, Gorlin R, Fuster V. Angiographic morphology and the pathogenesis of unstable angina pectoris. J Am Coll Cardiol 1985;5:609-616. 
22. Dorros G, Cowley MJ, Simpson et al. Percutaneous transluminal coronary angioplasty: Report of complications from the National Heart, Lung and Blood Institute PTCA registry. Circulation 1983;67:723-730.

23. Stenson RE, Flamm MD, Zaret BL, McGowan RL. Transient ST-segment elevation with postmyocardial infarction angina: Prognostic significance. Am Heart $J$ 1975;89:449454.

24. Marmor A, Sobel BE, Roberts R. Factors presaging early recurrent myocardial infarction ("extension"). Am J Cardiol 1981;48:603-610.

25. Simoons ML, Serruys PW, Brand van den M, Bar F, de Zwaan C, Res J, Verheugt FW, Krauss XH, Remme WJ, Vermeer F, Lubsen J. Improved survival after early thrombolysis in acute myocardial infarction. Lancet 1985;11:578581.

26. Fraker TD, Wagner GS, Rosati RA. Extension of myocardial infarction: Incidence and Prognosis. Circulation 1979;60: 1126-1129.

27. Schuster EH, Bulkley BH. Early post-infarction angina: Ischemia at a distance and ischemia in the infarct zone. $N$ Engl J Med 1981;305:1101-1105.

28. Madigan NP, Rutherford BD, Frye RL. The clinical course, early prognosis and coronary anatomy of subendocardial infarction. Am J Med 1976;60:635-641.

29. Hutter AM, De Sanctis RW, Flynn T, Yeatman LA. Nontransmural myocardial infarction: A comparsion of hospital and late clinical course of patients with that of matched patients with transmural anterior and transmural inferior myocardial infarction. Am J Cardiol 1981;48:595-602.

30. Gibson RS, Beller Ga, Gheorghiade M, Nygaard TW, Watson DD, Huey BL, Sayre SL, Kaiser DL. The prevalance and clinical significance of residual myocardial ischemia 2 weeks after uncomplicated non $\mathrm{Q}$ wave infarction: A prospective natural history study. Circulation 1983;73:11861198.

31. Gibson RS, Boden WE, Theroux P et al. Diltiazem and reinfarction in patients with non-Q-wave myocardial infarction. N Engl J Med 1986;315:423-9.

32. Davies GJ, Chierchia S, Maseri A. Prevention of myocardial infarction by very early treatment with intracoronary streptokinase. N Engl J Med 1984;311:1488.

33. Shapiro EP, Brinker JA, Gottlieb SO, Guzman PA, Bulkley $\mathrm{BH}$. Intracoronary thrombolysis 3 to 13 days after acute myocardial infarction for postinfarction angina pectoris. Am J Cardiol 1985;55:1453.

34. Levine FH, Gold HK, Leinbach RC, Daggett WM, Austen WG, Buckley MJ. Safe early revascularization for continuing ischemia after acute myocardial infarction. Circulation 1979;60(Suppl I):5-9.

35. Jones EL, Waikes TF, Craver JM, Bradford JM, Douglas JS, King SB, Bone DK, Dorney ER, Clements SD, Thompkins T, Hatcher CR. Coronary bypass for relief of persistent pain following acute myocardial infarction. Ann Thorac Surg 1981;32:33-43.

36. Nunley DL, Grunkemeier GL, Teply JF, Abbruzzese PA, Savis JS, Khonsari S, Starr A. Coronary bypass operation following acute complicated myocardial infarction. $J$ Thorac Cardiovasc Surg 1983;85:485-491.

37. Williams DB, Ivey TD, Bailey WW, Irey SJ, Rideout JT, Stewart D. Postinfarction angina: Results of early revascularization. J Am Coll Cardiol 1983;2:859-864.

38. Singh AK, Rivera R, Cooper GN, Karlson KE. Early myocardial revascularization for post infarction angina:
Results and long-term follow-up. J Am Coll Cardiol 1985;6: 1121-5.

39. Gertler JP, Elefteriades JA, Kopf GS, Hashim SW, Hammond GL, Geha AS. Predictors of outcome in early revascularization after acute myocardial infarction. Am J Surg 1985;149:441-44.

40. de Feyter PJ, Serruys PW, Soward A, van den Brand M, Bos E, Hughenholtz PG. Coronary angioplasty for early postinfarction unstable angina. Circulation 1986;74:1365-1370.

41. Gotlieb SO, Brin KP, Walford GD, McGaughey M, Riegel MB, Brinker JA. Percutaneous transluminal coronary angioplasty for early postinfarction unstable angina: Results and follow-up. $J$ Am Coll Cardiol 1986;7:20A (abstract).

42. Holt GW, Gersch BJ, Holmes DR, Vlietstra RE, Reeder CS, Bresnahan JF, Smith HC. The results of percutaneous transluminal coronary angioplasty in postinfarction angina. J Am Coll Cardiol 1986;7:62A (abstract).

43. Rentrop P, Blanke H, Karsch KR. Selective intracoronary thrombolysis in acute myocardial infarction and unstable angina pectoris. Circulation 1982;63:307-317.

44. Khaja F, Walton JA, Breymer JF et al.Intracoronary fibrinolytic therapy in acute myocardial infarction: Report of a prospective randomized trial. $N$ Engl J Med 1983;308: 1305-1311.

45. Anderson JL, Marshall HW, Bray BE et al. A randomized trial of intracoronary streptokinase in the treatment of acute myocardial infarction. $N$ Engl J Med 1983;308:1312-1318.

46. Kennedy JW, Ritchie JL, Davis KB, Fritz JK. Western Washington randomized trial of intracoronary streptokinase in acute myocardial infarction. $N$ Engl J Med 1983;309: $1477-1482$.

47. Leiboff $\mathrm{RH}$, Katz RJ, Wasserman AG et al. A randomized angiographically controlled trial of intracoronary streptokinase in acute myocardial infarction. Am $J$ Cardiol 1984;53:404-407.

48. Rogers WJ, Mantle JA, Hood WP et al. Prospective randomized trial of intravenous and intracoronary streptokinase in acute myocardial infarction. Circulation 1983; 68:1051-1061.

49. Rentrop P, Feit F, Blanke H et al. Effects of intracoronary streptokinase and intracoronary nitroglycerin infusion on coronary angiographic patterns and mortality in patients with acute myocardial infarction. $N$ Engl $J$ Med 1984;311: 1457-1463.

50. Raizner AE, Tortoledo FA, Verani MS, V. Reet RE. Intracoronary thrombolytic therapy in acute myocardial infarction: A propective, randomized controlled trial. Am J Cardiol 1985;55:301-308.

51. Simoons ML, Serruys PW, van den Brand M, et al. Improved survival after early thrombolysis in acute myocardial infarction. A randomised trial by the Interuniversity Cardiology Institute in the Netherlands. Lancet 1985;II:578581.

52. Meyer J, Merx W, Schmitz H, Erbel R, Kiesslich T, Dör R, Lambertz $\mathrm{H}$, Bethge $\mathrm{C}$, Krebs $\mathrm{W}$, Bardos $\mathrm{P}$, Minale $\mathrm{C}$, Messmer BJ, Effert S. Percutaneous transluminal coronary angioplasty immediately after intracoronary streptolysis of transmural myocardial infarction. Circulation 1982;66:905913.

53. Hartzler GO, Rutherford BD, McConahay DR, Johnson WL, McCallister BD, Gura GM, Conn RC, Crocket JE. Percutaneous transluminal coronary angioplasty with and without thrombolytic therapy for treatment of acute myocardial infarction. Am Heart $J$ 1983;106:965-973. 
54. Serruys PW, Wijns W, van den Brand M, Ribeiro V, Fioretti V, Simoons ML, Kooyman CJ, Reiber HJ, Hugenholtz PG. Is transluminal coronary angioplasty mandatory after successful thrombolysis? Br Heart $J$ 1983;50:257-265.

55. Bussmann WD, Hopf R, Schneider W. Direkte rekenalisierung durch transluminale angioplastie beim frischen herzinfarkt. Dtsch Med Wschr 1984;108:1383-1386.

56. Hartzler GO, Rutherford BD, McConahay DR. Percutaneous transluminal coronary angioplasty: Application for acute myocardial infarction. Am J Cardiol 1984;53:117C$121 \mathrm{C}$.

57. Pepine CJ, Prida X, Hill JA, Feldman RL, Conti CR. Percutaneous transluminal coronary angioplasty in acute myocardial infarction. Am Heart $J$ 1984;107:820-822.

58. Holmes DR, Smith HC, Vlietstra RE, Nishimara RA, Reeder GS, Bove AA, Bresnahan JF, Chesebro JH. Percutaneous transluminal coronary angioplasty, alone or in combination with streptokinase therapy during acute myocardial infarction. Mayo Clin Proc 1985;60:449-456.

59. Marco J, Caster L, Fajadet J. Emergency percutaneous transluminal coronary angioplastry without thrombolysis as an initial therapy in acute myocardial infarction. Int $J$ Cardiol 1987; 15:55-63.

60. Linnemeier TJ, Rothbaum DA, Landin RJ, Noble J. Percutaneous transluminal coronary angioplasty versus thrombolytic therapy in acute myocardial infarction. Circulation 1985;72:(Suppl III):111-456 (abstract).

61. O'Neill WW, Timmis GC, Bourdillon PD, Lai PY, Gangadharan V, Walton JA, Ramos RG, Laufer N, Gordon S, Schork A, Linert DP, Pitt B. A prospective randomized, trial of intracoronary streptokinase versus coronary angioplasty for acute myocardial infarction. $N$ Engl J Med 1986;314:812-818.

62. Rutherford BD, Hartzler GO, McConahay DR, Johnson WL. Direct balloon angioplasty in acute myocardial infarction without prior use of streptokinase. J Am Coll Cardiol 1986;7:149A (abstract).

63. Topol EJ, O'Neill WW, Lai P et al. Sequential intravenous thrombolysis and coronary angioplasty vs. direct PTCA therapy for acute myocardial infarction. J Am Coll Cardiol 1986;7:18A (abstract).

64. Gold HK, Cowley MJ, Palacios JF, Vetrovec GW, Akins CW, Block PC, Leinbach RC. Combined intracoronary streptokinase infusion and coronary angioplasty during acute myocardial infarction. Am J Cardiol 1984;53:122C$125 \mathrm{C}$.

65. Papapietro SE, Maclean WA, Stanley AW, Hess RG, Corley N, Arciniegas JG, Cooper TB. Percutaneous transluminal coronary angioplasty after acute intracoronary streptokinase in evolving acute myocardial infarction. Am J Cardiol 1985;55:48-53.

66. Erbel R, Pop T, Meinertz T, Kasper W, Schreiner G, Henkel B, Henrichs KJ, Pfeiffer C, Rupprecht HJ, Meyer J. Combined medical and mechanical recanalization in acute myocardial infarction. Cath Cardiovasc Diagn 1985;11:361377.

67. Prida XE, Holland P, Feldman RL, Hill JA, MacDonald RG, Conti R, Pepine CJ. Percutaneous transluminal coronary angioplasty in evolving acute myocardial infarction. Am J Cardiol 1986;57:1069-1074.

68. Kitazume H, Iwama T, Suzuki A. Combined thrombolytic therapy and coronary angioplasty for acute myocardial in- farction. Am Heart $J$ 1986; III:826-832.

69. Bredlau CE, Roubin GS, Leimgruber PP, Douglas JS, King SB, Grüntzig AR. Inhospital morbidity and mortality in patients undergoing elective coronary angioplasty. Circulation 1985;72:1042-1052.

70. Block PC. Percutaneous transluminal coronary angioplasty: Role in the treatment of coronary artery disease. Circulation 1985;72(suppl V):V-161.

71. Bache RJ, McHale PA, Greefield JC. Transmural myocardial perfusion during restricted coronary inflow in the awake dog. Am J Physiol 1977;232:H645.

72. Wyatt HL, Forrester JS, Tyberg JV, Goldner S, Logan SE, Parmley WW, Swan HJC. Effect of graded reductions in regional coronary perfusion on regional and total cardiac function. Am J Cardiol 1975;36:185.

73. Schmidt SB, Varghese PJ, Bloom S, Jackee Jm, Ross AM. The influence of residual coronary stenosis on size of infarction after reperfusion in a canine preparation. Circulation 1986;73:1354-1359.

74. Serruys PW, Simoons ML, Suryapranata H et al. Preservation of global and regional left ventricular function after early thrombolysis in acute myocardial infarction. J Am Coll Cardiol 1986;7:729-742.

75. Sheehan FH, Mathey DG, Schofer J, Dodge HT, Bolson EL. Factors that determine recovery of left ventricular function after thrombolysis in patients with acute myocardial infarction. Circualtion 1985;71:1121-1128.

76. Topol EJ, Weiss JL, Brinker JA, et al. Regional wall motion improvement after coronary thrombolysis with recombinant tissue plasminogen activator: Importance of coronary angioplasty. J Am Coll Cardiol 1985;6:426-433.

77. Erbel R, Pop T, Henricks K, Olshausen K, Schuster CJ, Ruprecht H, Steuernagel C, Meyer J. Percutaneous transluminal coronary angioplasty after thrombolysis therapy: A prospective controlled randomized trial. J Am Coll Cardiol 1986;8:485-495.

78. Hugenholtz PG, Rentrop P. Thrombolytic therapy for acute myocardial infarction: Quo vadis? Eur Heart J 1982;3:395.

79. Rentrop P. Thrombolytic therapy in patients with acute myocardial infarction. Circulation 1985;71:627-631.

80. Harrison DG, Ferguson DW, Collins SM, Skorton DJ, Ericksen EE, Kioschos JM, Marcus ML, White CW. Rethrombosis after reperfusion with streptokinase: Importance of geometry of residual lesions. Circulation 1984;69:991.

81. Schwartz F, Faure A, Katus H, Von Olshausen K, Hoffman M, Schuler G, Mathey J, Kubler W. Intracoronary thrombolysis in acute myocardial infarction: An attempt to quantitate its effect by comparison of enzymatic estimate of myocardial necrosis with left ventricular ejection fraction. Am J Cardiol 1983;51:1573.

82. Schröder R, Biamino G, Leitner ERV, Linderer T, Bruggeman KT, Heitz J, Vohringer HF, Wegschneider K. Intravenous short-term infusion of streptokinase in acute myocardial infarction. Circulation 1983;67:536.

83. Mathey DG, Schofer J, Sheenhan FH, Becker H, Tilsner V, Dodge HT. Intravenous urokinase in acute myocardial infarction. Am J Cardiol 1985;55:878.

84. Simoons ML, Serruys PW, van de Brand M et al. Early thrombolysis in acute myocardial infarction: Limitation of infarct size and improved survival. $J$ Am Coll Cardiol 1986;7:717-28. 